\title{
PERSEPSI MASYARAKAT DESA JIWAN TERHADAP KALENDER JAWA DALAM MEMBANGUN RUMAH
}

\author{
Berti Fitri Permatasari \& Novi Triana Habsari*
}

\begin{abstract}
Abstrak
Penelitian ini bertujuan untuk mengetahui persepsi atau pandangan masyarakat Desa Jiwan terhadap adanya Primbon dan Kalender Jawa dalam membangun rumah. Dalam penelitian ini menggunakan pendekatan kualitatif dan jenis penelitian interaksi simbolik yaitu terdapat makna-makna sosial yang akan diwariskan dan dilestarikan oleh masyarakat selanjutnya. Sumber data yang digunakan adalah sumber dara primer yaitu masyarakat yang dianggap paling memahami pengetahuan tentang tradisi Jawa atau sesepuh dan masyarakat Desa Jiwan pada umumnya. Sedangkan sumber sekunder adalah dokumen berupa profil desa. Teknik pengumpulan data melalui wawancara dan observasi. Teknik analisis data menggunakan komponen model interaktif melalui proses pemilihan data, penyajian data kemudian baru disimpulkan.

Pandangan masyarakat Jiwan terhadap kelender Jawa dalam membangun rumah masih dianggap penting. Terbukti bahwa ketika akan membangun atau pindah rumah masyarakat menentukan hari baik berdasarkan weton dari kalender Jawa dengan menghindari hari naas yaitu hari meninggalnya orang tua atau nenek. Mereka mempercayai hal tersebut dengan alasan mengikuti nasihat orang tua yang telah berpengalaman dan merupakan suatu adat sebagai masyarakat yang tinggal di tanah Jawa. Terdapat balutan kain berwarna merah putih sebagai ciri khas Bangsa Indonesia. Masyarakat melakukan slametan ketika membuat pondasi dan setelah rumah berdiri dengan menyiapkan sesaji berupa ayam panggang beserta perlengkapannya yang kemudian mengundang tetangga terdekat untuk melakukan doa bersama.
\end{abstract}

\section{Kata Kunci : Masyarakat Desa Jiwan, Kalender Jawa, Membangun Rumah}

\section{Pendahuluan}

Setiap manusia pada dasarnya mempunyai banyak kebutuhan, dalam pemenuhan kebutuhan tersebut manusia memiliki cara tersendiri untuk mendapatkannya. Sejak jaman nenek moyang seperti berburu, mengumpulkan makanan, bertanam dan lain sebagainya. Lambat laun pola tersebut mulai berubah mengikuti perkembangan jaman yang berlaku di masyarakat. Pada intinya manusia bergantung pada alam begitu pula sebaliknya alam membutuhkan kita untuk merawat dan melestarikannya. Dengan adanya kebiasaan itu maka terbentuklah suatu kebudayaan yang nantinya akan diwariskan kepada generasi penerusnya. "Kebudayaan diteruskan dari waktu ke waktu, kebudayaan yang telah lalu bereksistensi pada masa kini dan kebudayaan masa kini disampaikan ke masa yang akan datang" (Abraham dan Yudi, 2008:40).

Indonesia yang memiliki masyarakat multikultural, hal ini membuktikan bahwa wilayah Indonesia 
memiliki kebudayaan yang berbeda dengan ciri khas masing-masing. Salah satu diantaranya adalah di daerah pulau Jawa. Masyarakat Jawa terkenal dengan adat Kejawennya.

"Masyarakat Jawa adalah salah satu masyarakat yang sangat setia dan menjunjung tinggi norma, etika, estetika, adat istiadat dan budaya yang diwariskan secara turun temurun" (Muhammad Zaairul, 2011: 15). Adat atau kebudayaan dimulai dari lingkungan kerajaan atau keraton karena merupakan tempat keramat dan bersemayamnya seorang raja yang dipercaya sebagai tangan kanan atau perwujudan Tuhan di dunia dan memiliki kekuatan-kekuatan magis yang mengalir ke daerah dan membawa ketentaman, keadilan dan kesuburan (2011, 6-7).

Hal inilah kemudian dipercayai oleh sebagian besar masyarakat Jawa yang tinggal di seputar wilayah kerajaan untuk mengikuti tradisi yang telah ada di Kerajaan. Sehingga tradisi yang berawal dari Kerajaan dapat berkembang luas. Daerah yang mudah menerima tradisi dan pengaruh dari sebuah adat adalah masyarakat desa. Masyarakat desa identik dengan rasa kekeluargaan yang tinggi, mempunyai rasa saling memiliki dan tidak mudah untuk menerima perubahan-perubahan baru membuat tradisi yang telah diwariskan akan terus dipertahankan. Beberapa ciri masyarakat desa yang pertama, "mereka memiliki sifat yang homogen dalam hal mata pencaharian, nilai-nilai kebudayaan, sikap dan tingkah laku, kedua kehidupan di desa lebih menekankan anggota keluarga sebagai unit ekonomi, ketiga hubungan sesama anggota masyarakat lebih intim dan awet daripada di kota".

Selain itu masyarakat desa juga memiliki kepribadian seperti memiliki sifat menentang terhadap orang luar, artinya jika mereka sampai menyakiti perasaan dengan mencela adat mereka hal yang dapat terjadi adalah tidak mudah untuk merubah pendiriannya, masyarakat desa sangat toleran dengan nilai-nilai yang dimilikinya dan memiliki sikap pasrah pada yang Maha Kuasa (Jefta Leibo, 1990: 3-4).

$$
\text { Masyarakat desa meyakini }
$$
apabila suatu tradisi yang telah diciptakan oleh leluhurnya terus dilakukan maka dalam kehidupannya akan mendapatkan berkah dan kebaikan dari sang pencipta.

Menurut Suprihadi dan Soehartono, 1984: 6 mengatakan bahwa :

Salah satu ciri masyarakat desa adalah keeratan dan kepatuhan mereka terhadap adapt istiadat masyarakatnya. Mereka adalah masyarakat yang terikat erat oleh kebiasaan-kebiasaan dan 
tradisinya. Oleh sebab itu, siapapun dan bagaimanapun keadaan mereka biasanya akan menjunjung tinggi adat istiadat mereka. Keterikatan mereka terhadap tradisi dan adapt menyebabkan mereka cukup tangguh untuk tetap memegang teguh apa kata nenek moyang dan apa yang diterima sebagai kebenaran oleh masyarakatnya.

Dari adanya tradisi akan muncul suatu kebiasaan yang mereka laksanakan dihari khusus dengan maksud dan tujuan tertentu. Salah satunya seperti melakukan upacara-upacara selamatan. Dengan tradisi yang sedemikian ini maka masyarakat menyebut sebagai budaya lokal dengan memiliki ciri khas yang berbeda.

Menurut Abraham dan Yudi (2008: 38) dikatakan bahwa "kebudayaan adalah seluruh cara kehidupan dari masyarakat yang tidak hanya mengenai sebagian tata cara kehidupan saja yang dianggap paling tinggi dan diinginkan. Kebudayaan menunjuk pada berbagai aspek kehidupan meliputi cara-cara berlaku, kepercayaan-kepercayaan dan sikap dan juga hasil kegiatan manusia yang khas untuk suatu masyarakat tertentu atau kelompok penduduk tertentu".

Kebudayaan juga memiliki nilai-nilai yang diyakini masyarakat sebagai dasar pemaknaan khusus, dibuktikan melalui ungkapan rasa syukur kepada sang Pencipta alam semesta. Nilai ini yang menjadi dasar sebagian masyarakat untuk tetap menjaga, melestarikan dan mempertahankan budaya yang telah diwariskan dari nenek moyang sebelumnya. "Nilai-nilai budaya adalah jiwa dari kebudayaan dan menjadi dasar segenap wujud kebudayaan. Di samping nilai-nilai kebudayaan, kebudayaan diwujudkan dalam tata hidup yang merupakan kegiatan manusia yang mencerminkan nilai budaya yang dikandungnya" (Abraham dan Yudi, 2008: 40).

Salah satu contoh adat Jawa yang berhubungan dengan pemenuhan kebutuhan yang lebih riil seperti membangun atau mendirikan rumah. Karena rumah merupakan tempat dimana manusia dapat belajar mewarisi dan melestarikan segala sesuatu yang telah diberikan orang-orang terdahulu. Manusia wajib memiliki rumah sebagai tempat berlindung dan juga sebagai awal pembelajaran adanya suatu budaya yang ada.

Untuk mendirikan rumah masyarakat percaya akan adanya penentuan hari baik, mempertimbangkan segala sesuatu yang dianggap baik bahkan sampai memberikan sesaji agar nantinya rumah 
tersebut menjadi aman dan sejahtera bagi para penghuninya. Dalam mendirikan rumah masyarakat tersebut berpedoman pada suatu catatan yang dibuat oleh nenek moyang berdasarkan pengalaman disesuaikan dengan kejadian pada setiap harinya yang orang-orang menyebutnya sebagai primbon. Sehingga dengan kata lain para pendahulu teliti dan hati-hati dalam bertindak agar tidak terulang kembali dan selalu mendapatkan kebaikan. "Nenek moyang orang Jawa beranggapan bahwa semua benda yang ada di sekelilingnya itu bernyawa, dan semua yang bergerak dianggap hidup dan mempunyai kekuatan gaib atau mempunyai roh yang berwatak baik maupun jahat" Kuntjaraningrat (dalam Budiono, 1987: 98).

Daldiono, Wistodiyono (2010: 49) menyatakan bahwa "rumah tidak hanya sebuah bangunan untuk tempat berteduh dan beristirahat akan tetapi menurut nenek moyang Jawa digunakan sebagai perlambangan manembah kepada Sang Hyang Maha Wasesa. Jika diperhatikan lebih seksama bagian teratas rumah selalu merupakan pertemuan dua bidang yang melambangkan dua tangan yang bertemu terkatup pada jari tangan kanan dan jari tangan kiri dengan telapak tangan terbuka satu sama lain". Dengan demikian masyarakat desa khususnya orang Jawa enggan untuk meninggalkan upacara mendirikan atau membangun rumah dan pindah rumah karena mereka memiliki hubungan erat antara kepercayaan nenek moyang dengan ungkapan rasa syukur kepada sang Pencipta dan menginginkan kehidupan bahagia sejahtera di dalam rumah.

Seiring berjalannya waktu dengan kehidupan manusia yang lebih modern dan dibuktikan dengan adanya teknologi yang semakin canggih, pola pikir manusia yang mulai berubah mempengaruhi pergeseran budaya sehingga mulai banyak yang meninggalkan tradisi mereka. Hal-hal yang dianggap penting oleh masyarakat jaman dulu mulai terabaikan oleh masyarakat jaman sekarang karena tidak adanya bukti konkrit sehingga hanya dianggap sebagai mitos belaka. Akibatnya budaya setempat mengalami guncangan. "Guncangan budaya yaitu ketidaksesuaian unsur-unsur yang saling berbeda sehingga menghasilkan suatu pola kehidupan sosial yang tidak serasi fungsinya bagi masyarakat yang bersangkutan" (Abraham dan Yudi, 2008: 84).

\section{Kajian Pustaka}

1. Persepsi

Menurut Sarlito Wirawan (2002: 94) "persepsi adalah proses pencarian informasi untuk dipahami. Alat untuk 
memperoleh informasi tersebut berupa pengindraan (penglihatan, pendengaran, perabaan dan sebagainya) sedangkan alat untuk memahaminya adalah kesadaran atau kognisi." Dijelaskan bahwa Persepsi atau sudut pandang ialah "suatu titik tolak pemikiran yang tersusun dari seperangkat kata-kata yang digunakan untuk memahami kejadian atau gejala dalam kehidupan" (Elly dkk, 2007: 32). Persepsi juga merupakan "sejenis aktivitas pengelolaan informasi yang menghubungkan seseorang dengan lingkungannya" (Fattah, 2010: 34).

Dari pendapat tersebut diatas dapat disimpulkan bahwa persepsi merupakan pandangan atau pemahaman seseorang terhadap fenomena yang terjadi dalam lingkungan kehidupannya melalui alat pengindraan secara sadar untuk mengelola informasi penting. Dalam hal ini persepsi yang dibutuhkan mengenai pemahaman seseorang terhadap suatu realitas sosial atau yang disebut sebagai persepsi sosial (Fattah, 2010: 34).

2. Masyarakat

Ralp Lonton (dalam Harsojo 1986: 126) mengemukakan bahwa "masyarakat merupakan setiap kelompok manusia yang telah cukup lama hidup dan bekerja sama sehingga mereka dapat mengorganisasikan dirinya dan berpikir tentang dirinya sebagai satu kesatuan sosial dengan batas-batas tertentu". Menurut Mac Iver dan Page (dalam Dadang Supardan, 2008: 28) dijelaskan bahwa "masyarakat ialah suatu sistem dari kebiasaan dan tata cara dari wewenang dan kerja sama antara berbagai kelompok dan penggolongan, dari pengawasan tingkah laku serta kebebasan-kebebasan manusia". "Dalam bahasa Inggris disebut society yang berasal dari bahasa Latin socius yang artinya 'kawan'. Dalam bahasa arab, kata masyarakat berasal dari kata syaraka yang berarti ikut serta atau berpartisipasi. Masyarakat adalah sekumpulan manusia yang saling 'bergaul' atau saling 'berinteraksi'. Lebih lengkapnya bahwa definisi masyarakat merupakan sebagai kesatuan hidup manusia yang berinteraksi menurut suatu kesatuan sistem adat istiadat tertentu yang bersifat kontinu dan yang terikat oleh suatu rasa idenitas bersama" (Koenjaraningrat, 2009: 116,118).

Dari ketiga pendapat diatas maka dapat diketahui bahwa masyarakat adalah sekumpulan manusia yang hidup bersama dalam suatu wilayah tertentu dalam waktu yang cukup lama, saling membutuhkan satu sama lain dan menghasilkan suatu kebudayaan atau kebiasaan berdasarkan nilai dan norma yang 
berlaku. Masyarakat erat kaitannya dengan kebudayaan, karena kebudayaan diciptakan oleh manusia dengan mengandalkan rasa dan karsa mereka.

a. Ciri-ciri Masyarakat

Anderson dan parker (dalam Abraham dkk, 2009: 48) menyatakan bahwa ciri-ciri masyarakat adalah sebagai berikut :

1. Adanya sejumlah orang

2. Bertempat tinggal dalam suatu daerah tertentu

3. Mengadakan hubungan satu sama lain

4. Saling terikat satu sama lain karena mempunyai kepentingan bersama

5. Merupakan satu kesatuan sehingga mereka mempunyai perasaan solidaritas

6. Adanya saling ketergantungan

7. Merupakan satu sistem yang diatur oleh norma-norma atau aturan-aturan tertentu

8. Menghasilkan suatu kebudayaan

b. Unsur-unsur Masyarakat

Unsur dalam suatu masyarakat meliputi lima bagian diantaranya adalah sebagai berikut, pertama kategori sosial yaitu kesatuan manusia yang terwujud karena adanya suatu ciri atau suatu kompleks ciri-ciri obyektif atau dikenakan kepada pihak luar tanpa disadari oleh yang bersangkutan pada kesatuan manusia tersebut. Kategori sosial tidak terikat oleh kesatuan adat, sistem nilai atau norma tertentu, tidak mempunyai organisasi dan pimpinan, contohnya kategori warga di bawah umur 18 tahun. Kedua golongan sosial merupakan suatu kesatuan manusia yang ditandai oleh suatu ciri tertentu yang terikat oleh sistem nilai, sistem norma dan adat istiadat, contohnya golongan pemuda. Ketiga komunitas dan keempat adalah kelompok dan perkumpulan. (Koentjaraningrat, 2009: 115,120-125).

3. Kalender Jawa

$$
\begin{aligned}
& \text { Kalender Jawa disebut juga } \\
& \text { dengan Petangan Jawi yaitu } \\
& \text { "perhitungan baik buruk yang } \\
& \text { dilukiskan dalam lambang dan watak } \\
& \text { suatu hari, tanggal, bulan tahun pranata } \\
& \text { mangsa, wuku dan lain sebagainya" } \\
& \text { (Purwadi, 2009: 23). Menurut Suwardi } \\
& \text { (2010: 102) "petung atau perhitungan } \\
& \text { merupakan pertimbaangan memet } \\
& \text { (sungguh-sungguh), memanfaatkan } \\
& \text { nalar jelas, disertai laku tertentu ... } \\
& \text { petungan didasarkan atas peredaran } \\
& \text { matahari, bulan, bintang dan planet lain } \\
& \text { untuk meramal nasib". Dari tersebut } \\
& \text { dapat disimpulkan bahwa kalender Jawa } \\
& \text { adalah perhitungan dari nenek moyang } \\
& \text { orang Jawa yang didasarkan atas adanya } \\
& \text { fenomena alam dalam meramal hal baik }
\end{aligned}
$$


dan buruk ketika akan bertindak dalam hidup.

Masyarakat Jawa menganggap bahwa petungan merupakan sebuah jati diri sehingga sulit dihilangkan dalam benar mereka dan selalu memperhitungkan gerak dan langkah hidup agar mereka selamat dan selalu mendapat perlindungan dari Sang Maha Kuasa. Kalender Jawa ini sudah ada sebelum masuknya agama Hindu di Indonesia dengan nama Pranata Mangsa. Kalender ini digunakan masyarakat jawa khususnya kaum petani sebagai pedoman bekerja. Ketika Jawa mendapat pengaruh dari Hindu dan terdapat sebuah kerajaan bernama Mataram kemudian kalender diganti menjadi kalender saka atau tahun saka. Tahun saka ini adalah nama seorang raja bernama Raja Sariwahana Ajisaka yang menciptakan huruf Jawa atau Dentawiyanjana (ha na ca $r a \quad k a)$. Kalender saka dimulai pada tahun 78 Masehi.

Pada masa pemerintahan Isalam kalender Jawa disebut juga kalender Sultan Agung yang mengikuti sistem lunair (Komariah) yaitu perjalanan bulan mengitari bumi seperti kalender Hijriyah. Nama-nama kalender Jawa sebagai berikut : Sura, Sapar, Mulud, Bakda Mulud, Jumadil Awal, Jumadil Akhir, Rejeb, Ruwah, Pasa, Syawal, Dulkangidah dan Besar.
Hari dalam perhitungan Jawa berjumlah tujuh yang disebut dina pitu dan pasaran berjumlah lima disebut pasaran lima, atau sering disingkat dina lima dina pitu. Keduanya akan menentukan jumlah neptu dina (hidupnya hari dan pasaran). Pasaran yang dimaksud meliputi Pon (7), Wage (4), Kliwon (8), Legi (5) dan Pahing (9), sedangkan harinya adalah seperti hari biasa dari Senin hingga Sabtu. Dengan menentukan perhitungan antara hari dan pasaran kemudian akan mendapatkan jawaban atau ramalan dari berbagai hal sesuai yang diinginkan (Suwardi, 2010: 103).

\section{Metode Penelitian}

Lokasi penelitian ini adalah di Desa Jiwan Kecamatan Madiun. Sedangkan waktu penelitian yang digunakan bulan februari sampai Juli 2012. Pendekatan penelitian menggunakan pendekatan kualitatif yang merupakan penelitian dilatarbelakangi oleh aktivitas masyarakat dan berbagai kegiatan sosial lainnya. Dalam pendekatan kualitatif yang menjadi sasaran penelitian adalah kehidupan sosial atau masyarakat. Landasan berpikir untuk memahami suatu gejala yang sesuai dalam penelitian ini adalah interaksi simbolis atau hubungan yang memiliki makna simbolis. Dari sudut pandang teori dan pendekatan interaksi simbolis ini 
mengacu pada semua perilaku manusia yang memiliki dasar makna-makna sosial. Makna-makna sosial dari perilaku manusia yang melekat pada dunia sekitarnya itu penting untuk dipahami, (Emy Susanti dalam Bagong dan Sutinah, 2008: 167). Artinya masyarakat percaya bahwa apa yang dilakukan sebelum beraktifitas seperti syaratsyarat dalam membangun atau pindah rumah memiliki makna khusus sehingga enggan untuk ditinggalkan. Tradisi ini dimulai dari mulut ke mulut sehingga melalui proses interaksi tersebut.

Jenis penelitian yang digunakan yaitu Ekologis, menurut Roger Barker dan Herbert Wright (dalam Dede Oetomo, 2008: 180-181) memandang bahwa "individu dan lingkungannya saling bergantung, masyarakat mulai pemerian yang murni dan rinci tentang individu dalam lingkungannya .... yang kemudian di analisis dalam kaitannya dengan tindakan-tindakan yang dianggap diarahkan oleh tujuan-tujuan tertentu". Sumber data yang digunakan dalam penelitian meliputi:

1. Sumber Primer

Sumber primer atau sumber utama yaitu sumber data yang langsung memberikan data kepada pengumpul data (Sugiyono, 2007: 225). Artinya dalam pengumpulan data dilakukan melalui wawancara dengan pihak yang bersangkutan. Orang yang akan memberikan informasi dalam wawancara disebut nara sumber. Dalam penelitian ini wawancara dilakukan dengan perangkat desa, orang yang dipercaya sebagai sesepuh dan masyarakat Jiwan yang telah melakukan pindah ataupun membangun rumah.

2. Sumber Data Sekunder

Data sekunder adalah sumber yang tidak langsung memberikan data kepada pengumpul data, seperti dokumen, foto, (Sugiyono, 2007: 225). Data yang dikumpulkan dalam penelitian ini adalah profil desa dan demografi desa Jiwan.

Teknik pengumpulan data yang akan digunakan dalam penelitian ini adalah sebagai berikut :

1. Observasi

Menurut Husaini dan Purnomo (2004: 54) "observasi ialah pengamatan dan pencatatan yang sistematis terhadap gejala-gejala yang diteliti. Teknik ini hasrus sesuai dengan tujuan penelitian dan dapat dikontrol keandalannya dan kesahihannya".

"Observasi atau pengamatan adalah kegiatan keseharian manusia dengan menggunakan panca indra sebagai alat Bantu utamanya selain panca indra lainnya seperti telinga, penciuman, mulut dan kulit" (Burhan Bungin, 2007: 115). Menurut Nasution (dalam Sugiyono, 2007: 
menyatakan bahwa observasi adalah dasar semua ilmu pengetahuan, sebab dengan adanya observasi dapat mengetahui fakta yang diteliti dalam lingkungan masyarakat.

Observasi atau pengamatan juga dapat didefinisikan sebagai 'perhatian yang terfokus terhadap kejadian, gejala atau sesuatu' (Emzir, 2011: 37). Sehingga dari keempat pendapat diatas dapat disimpulkan bahwa observasi adalah suatu kegiatan pengamatan untuk mendapatkan informasi bagi para peneliti dengan fakta-fakta yang telah terungkap yang terjadi di lingkungan masyarakat.

2. Wawancara

Menurut Suharsimi, 1989: 126 "wawancara atau kuisioner lisan adalah sebuah dialog yang dilakukan oleh pewawancara (interviewer) untuk memperoleh informasi dari terwawancara". "Wawancara merupakan pertemuan dua orang untuk bertukar informasi dan ide melalui tanya jawab, sehingga dapat dikonstruksikan makna dalam suatu topik tertentu" (Esterberg dalam Sugiyono, 2007: 231).

Menurut kedua pendapat diatas maka dapat disimpulkan bahwa wawancara ialah bertemunya antara peneliti dengan responden yang mengadakan tanya jawab untuk memperoleh informasi yang dibutuhkan oleh peneliti lebih mendalam. Terdapat dua macam wawancara yang digunakan dalam penelitian ini, pertama wawancara semistruktur dan kedua wawancara tidak berstruktur. Wawancara semiterstruktur adalah jenis wawancara yang pelaksanaannya lebih bebas dengan tujuan untuk menemukan informasi secara lebih terbuka dimana responden dapat mengemukakan pendapat dan ideidenya. Sedangkan wawancara tidak berstruktur adalah wawancara yang bebas di mana peneliti tidak menggunakan pedoman wawancara, hanya menggunakan garis besar masalah yang akan ditanyakan (Sugiyono, 2007: 233). Dalam penelitian ini orang-orang yang terlibat adalah para sesepuh Desa Jiwan dan Masyarakat Jiwan.

3. Dokumentasi

$$
\text { Dokumentasi merupakan }
$$
catatan peristiwa yang sudah berlalu berupa tulisan, gambar atau karyakarya monumental dari seseorang (Sugiyono, 2007: 240). Menurut Husaini dan Purnomo (2004,73) mendefinisikan dokumentasi sebagai pengambilan data yang diperoleh melalui dokumen-dokumen. Keuntungan menggunakan dokumentasi ini biayanya relative murah, waktu dan tenaga lebih efisien. 
Sedangkan kelemahannya data yang diambil cenderung lama dan kalau salah cetak maka peneliti ikut salah dalam mengambil datanya.

Analisis data dalam penelitian ini menggunakan analisis interaktif. Komponen analisis data dengan menggunakan model interaktif tersusun atas tiga hal yaitu :

1. Reduksi data

Reduksi data diartikan
sebagai "proses pemilihan,
pemusatan perhatian pada
penyederhanaan, pengabstakan dan
transformasi data 'kasar' yang
muncul dari catatan lapangan"
(Matthew B, 1992: 16). Dengan
demikian peneliti harus
merangkum, memilih hal-hal yang pokok dan memfokuskan pada halhal yang penting saja.

2. Penyajian Data

Penyajian data merupakan "sekumpulan informasi tersusun yang memberi kemungkinan adanya penarikan kesimpulan dan pengambilan data" (Matthew B, terjemahan Tjetjep Rohendi, 1992: 17). Penyajian ini dapat berupa grafik, tabel dan lain sebagainya. Penyajian data ini memudahkan untuk memahami yang telah diteliti.

3. Verifikasi

Verifikasi yaitu kesimpulan dari keseluruhan atau menjawab dari rumusan masalah. Temuan dapat berupa deskripsi atau gambaran suatu objek yang sebelumnya samara menjadi jelas setelah diteliti (Sugoyino, 2010: 345).

Dari keterangan diatas dapat

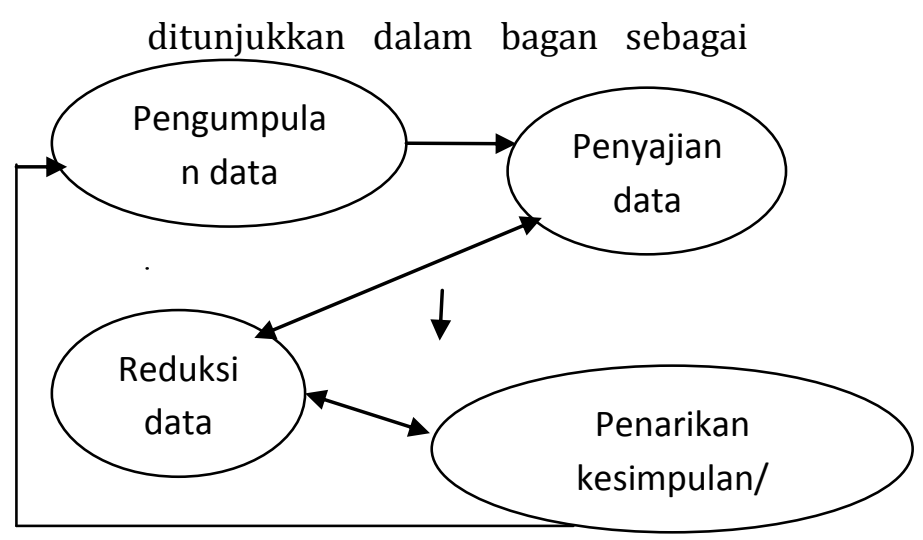

Bagan 1. Komponen Model Interaktif

(Matthew B, terjemahan Tjetjep Rohendi, 1992: 20).

\section{Hasil Penelitian}

\section{A. Persepsi Masyarakat Desa Jiwan tentang Kalender Jawa}

Primbon merupakan sebuah catatan yang dibukukan oleh nenek moyang berisi tentang ramalan-ramalan tindakan manusia. Dalam primbon terdapat pemaknaan dari simbol-simbol tradisional yang berkaitan dengan tingkah laku, angan-angan dan mimpi. Nenek moyang jaman dahulu sangat memperhatikan segala sesuatu dengan teliti. Hal ini bertujuan agar tidak terjadi hal buruk di kemudian hari (wawancara. Karjoko: 20 Mei 2012). 
Keberadaan primbon difungsikan sebagai patokan atau pedoman orang Jawa ketika akan melakukan hal-hal penting seperti misalnya hajatan pernikahan, menjodohkan anak, mendoakan keluarga yang sudah meninggal dan ketika akan mendirikan rumah atau pindah rumah. Sebelum melaksanakan segala aktivitas yang dilakukan pertama kali adalah mempertimbangkan hal baik agar nantinya berjalan lancar sesuai dengan rencana yang telah ditetapkan. Akan tetapi primbon hanya sebagai ramalan saja benar atau tidaknya tergantung pada kepercayaan masingmasing dan manusia hanya berserah diri pada sang Pencipta (wawancara. Hartini: 20 Mei 2012)

Kepercayaan terhadap warisan nenek moyang atau sesepuh seperti hanya selalu mempertimbangkan hal baik dan menghindari hal buruk melalui tuntunan dari buku harian jaman dahulu (primbon) masih dianggap penting oleh sebagian masyarakat Jiwan. Masih banyak masyarakat yang mempercayai keberadaannya tetapi mereka tidak meninggalkan ajaran agama (percaya pada Allah SWT). Walupun tidak teliti seperti orang-orang jaman dahulu untuk memenuhi syarat, masyarakat sekarang hanya mengambil bagian-bagian inti saja seperti ucapan syukur melalui selamatan (berdoa kepada Tuhan) dengan mengundang tetangga dekat. Karena menurut mereka apabila tidak dilaksanakan atau diabaikan percaya tidak percaya pantangan itu menjadi kenyataan (wawancara. Sumarmi: 14 Mei 2012).

Banyak contoh hal-hal buruk yang telah terjadi, oleh sebab itu mereka mulai berhati-hati dan mengikuti apa yang telah diramalkan dalam buku. Ketika akan melakukan sesuatu yang dianggap penting misalnya dalam membangun rumah, untuk menemukan hari baik mereka menghindari hari naas (hari meninggalnya orangtua dan nenek). Selain itu apabila akan membangun rumah apabila ada keluarga yang mengandung mereka menyarankan untuk menundanya terlebih dahulu demi keselamatan Ibu maupun janinnya (wawancara. Sumarmi: 14 Mei 2012).

\section{B. Bentuk Implementasi Kelender Jawa di Desa Jiwan}

Kepercayaan terhadap primbon oleh sebagian masyarakat Jiwan masih dianggap penting karena di dalamnya terdapat ramalan penting berkaitan dengan perhitungan kalender Jawa sebagai pedoman masyarakat dalam bertindak. Dalam hal ini yang enggan mereka tinggalkan seperti halnya penentuan hari baik dalam melaksanakan hajatan pernikahan, menjodohkan anak, mendoakan 
keluarga yang sudah meninggal, mendirikan rumah bersamaan dengan pembuatan sumur (sumber air) dan pindah rumah sampai saat panen tiba (methil). Dalam menentukan hari ketika akan melakukan hajatan, perjodohan yang diingat adalah menghindari hari naas yaitu hari dan tinggal dimana ada keluarga yang meninggal.

Setelah menentukan hari baik memberikan syarat berupa sesaji dan melakukan selamatan sebagai ucapan syukur kepada Tuhan adalah wajib dilaksanakan oleh masyarakat Jiwan. Pada dasarnya suatu tradisi dilakukan untuk memeproleh keselamatan dari Sang Pencipta dan memperoleh kebahagiaan jiwa dan raga mereka. Mayoritas masyarakat Jiwan percaya bahwa lingkungan disekitarnya dianggap hidup dan sebagai manusia biasa pasti akan mengalami berbagai cobaan dari Sang Maha Kuasa. Oleh sebab itu mereka melakukan yang terbaik demi keselamatan keluarga dan berusaha melaksanakannya selagi mereka mampu. Kegiatan atau tradisi ini hanya sebagai simbol yanag pada akhirnya semua hanya kehendak Tuhan.

Hasil dari wawancara menyebutkan mayoritas mempercayai tradisi Jawa khususnya dalam mendirikan rumah. Kriteria dalam mendirikan rumah diantaranya mempersiapkan bahan bangunan yang akan digunakan, menentukan hari baik, melakukan peletakan batu pertama dan melakukan selamatan, mendirikan tiang utama (soko guru), mendirikan molo (atap kayu) disertai kain putih atau merah yang dibalutkan pada kayu dan yang terakhir adalah melakukan selamatan kembali setelah rumah berdiri.

Pada jaman dahulu rumah menghadap ke utara atau selatan dengan alasan tidak menghadang matahari dari arah timur dan barat. Akan tetapi seiring berjalannya waktu hal tersebut mulai ditinggalkan. Untuk menentukan arah rumah menghadap arah jalan utama. Rumah-rumah yang ada di Desa Jiwan juga mengalami perubahan. Banyak rumah yang tidak menggunakan soko guru dan bentuk rumah banyak dipengaruhi dari arsitektur Eropa sehingga semakin modern.

Seperti contoh hampir semua rumah di Dusun Bagag, arah rumah menghadap jalan utama yaitu ke arah Timur dan Barat. Pendirian soko guru hanya terdapat pada rumah tradisional jawa yaitu di rumah Bapak Narto, Bapak Djawawi dan Bapak Totok. Sedangkan rumah-rumah yang berdiri sekarang ini bentuknya sudah modern sehingga pendirian soko guru tergantung bentuk rumah dan sesuai dengan keinginan pemilik rumah. Tradisi yang mereka 
lakukan hanya selamatan pada saat peletakan batu pertama dan saat rumah sudah berdiri.

\section{Pembahasan}

\section{A. Pandangan Masyarakat Desa Jiwan} Terhadap Kalender Jawa Dalam Membangun Rumah

Keberadaan primbon yang didalamnya terdapat makna simbolis orang-orang jaman dahulu berkaitan dengan tingkah laku, angan-angan dan mimpi masih dianggap penting oleh sebagian masyarakat Desa Jiwan. Mayoritas masyarakat Jiwan mempercayai tradisi-tradisi Jawa khususnya dalam membangun rumah. Alasan mereka masih mempercayai keberadaan ramalan jaman dahulu disebabkan banyak kejadian buruk apabila mengabaikan nasihat dari orang yang lebih tua yang berpedoman pada primbon tersebut.

Dari hasil penelitian juga menyebutkan bahwa sebagian besar masyarakat Jiwan percaya dengan alasan banyak terbukti adanya halangan buruk yang terjadi apabila tidak mengikuti ramalan dari Primbon, merupakan pengalaman orang tua yang tidak ada salahnya apabila dilaksanakan, merupakan adat Jawa yang telah turun temurun dan suatu kepercayaan pribadi yang enggan bila ditinggalkan.

Pedoman yang mereka terapkan tidak sama persis dengan apa yang ada di dalam buku seperti syaratsyarat dalam sesaji mulai berkurang, sehingga hanya sebagian yang dianggap penting seperti mempertimbangkan hal baik dan mengadakan slametan sebagai ungkapan rasa syukur. Pada dasarnya tradisi yang mereka lakukan hanya sebagai simbol karena mereka masih berpegang teguh pada ajaran agama (percaya pada Allah SWT). Mereka beranggapan karena merasa tinggal di tanah Jawa maka mau tidak mau harus mengikuti tradisi yang telah diturunkan oleh nenek moyang.

\section{B. Penerapan Kepercayaan Masyarakat} Jiwan Tentang Kalender Jawa Dalam Tradisi Membangun Rumah

$\begin{array}{lll} & \text { Rumah merupakan tempat } \\ \text { tinggal yang dalam waktu jangka } \\ \text { panjang akan dihuni oleh sebuah }\end{array}$
keluarga. Tradisi Jawa menjelaskan bahwa ketika seseorang akan membangun rumah harus memperhatikan segala sesuatu demi keselamatan baik anggota keluarga maupun harta benda. Dalam sub bab ini akan diuraikan tentang syarat-syarat ketika akan membangun rumah. Kriteria dalam mendirikan rumah diantaranya mempersiapkan bahan banguan yang akan digunakan, menentukan hari baik, melakukan peletakan batu pertama bersamaan dengan acara slametan (doa bersama), membuat pondasi, mendirikan tiang utama (soko guru), 
mendirikan molo (atap kayu) disertai kain putih, merah atau merah putih yang dibalutkan pada kayu, melakukan ritual dengan mengumpulkan bunga setaman (bunga mawar dan bunga mayang) dan yang terakhir adalah melakukan slamatan kembali setelah rumah berdiri. Dalam menentukan hari baik mereka mempertimbangkan halhal yang dianggap penting dengan menghindari hari-hari naas yaitu hari dan tanggal dimana bertepatan dengan meninggalnya orang tua atau nenek.

Setelah mendapatkan hari baik yang dihitung berdasarkan weton dari orang yang punya hajad dalam mendirikan rumah. Di dalam buku primbon terdapat ramalan agar rumah kelak menjadi aman sebagai pertanda untuk meminta pertolongan dengan menggunakan perhitungan neptu yaitu jumlah hari ditambah dengan jumlah pasaran dalam kalender Jawa. Sebagai contoh dalam menentukan hari baik apabila seseorang akan mendirikan rumah pada hari Jumat Legi nilainya adalah Jumat berjumlah 6 dan Legi berjumlah 5 sehingga $6+5=11$, kemudian dihitung dengan cara adalah sebagai berikut :

1. Kerta

2. Jasa

3. Candi

4. Rogoh

5. Sempoyongan
6. Kerta

7. Jasa

8. Candi

9. Rogoh

10. Sempoyongan

11. Kerta

Karena jumlahnya 11 maka perhitungan hanya sampai ke 11 yaitu jatuh pada kerta begitu pula selanjutnya sesuai jumlah neptu masing-masing orang. Perhitungan ini untuk menghindari arti dari Rogoh yang berarti buruk bagi pemikil rumah.

Keterangan:

1. Kerta artinya mendapat banyak rejeki

2. Jasa artinya kuat sentosa

3. Candi artinya selamat sejahtera

4. Rogoh artinya seringkali dimasuki pencuri atau kematian

5. Sempoyongan artinya kerap kali pindah, jatuh dan tidak tahan lama untuk didiami.

Langkah selanjutnya adalah penentuan waktu. Dalam penentuan waktu ini hanya sebagai syarat saja sehingga dapat dilanjutkan kembali ke esokan harinya. Kemudian saat pembangunan pondasi harus membuat takir sebanyak 5 buah yang di dalamnya berisi rempah-rempah, telur, bunga dan uang koin disertai dengan jenang sengkala. Takir ini diletakkan di sudutsudut rumah 1 takir diletakkan 
ditengah. Takir tersebut biasanya didampingi kendi kecil yang diisi air yang berfungsi sebagai agar di dalam rumah menjadi dingin. Diberikannya takir-takir ini sebagai penolak bala yaitu penolak halangan buruk, penolak penyakit dan atau terjadi kejahatan di dalam rumah.

Di dalam rumah biasanya terdapat balutan kain berwarna merah putih disertai dengan paku emas diletakkan pada kayu atap rumah (molo) memberikan arti bahwa ciri khas bendera Indonesia dan watak orang yang mempunyai rumah dapat berjiwa pemberani, di dalam rumah menjadi bersih dan suci. Sedangkan emas menandakan kewibawaan seseorang agar bersinar seperti emas (wawancara. Sumarmi: 14 Mei 2012).

Syarat lain seperti misalnya tiang utama (soko guru) yang terdapat di ruang utama rumah mulai jarang ditemukan. Rumah jaman dahulu menghadap ke utara atau selatan dengan alasan tidak menghadang matahari dari arah timur dan barat. Akan tetapi seiring berjalannya waktu hal tersebut mulai ditinggalkan. Untuk menentukan arah rumah mereka memperhatikan arah jalan utama.

Slametan dilakukan ketika membuat pondasi dan setelah pendirian kerangka atap rumah. Dalam slametan yang perlu disediakan adalah nasi tumpeng, ayam panggang dan perlengkapannya, jenang sengkala, pisang raja dan buah palapendem. Acara slametan ini adalah upacara sedekah makanan sebagai ungkapan rasa syukur kepada Tuhan karena telah terselesaikannya pembangunan rumah dengan disuguhi dari hasil tanaman bumi (palapendem) dan jenang sengkala, jenang sengkala adalah bubur beras berwarna merah dan putih sebagai penolak bala (halangan/kejahatan/penyakit). Syarat membangun rumah hampir sama dengan pindah rumah. Ketika orang akan pindah rumah/boyongan yang perlu dilakukan adalah membawa tikar dan bantal untuk tidur dirumah yang akan ditempati dengan alasan agar nantinya nyaman atau betah berada di rumah tersebut.

Seiring berjalannya waktu dalam melakukan selamatan banyak masyarakat yang hanya menyiapkan ayam panggang beserta perlengkapannya saja kemudian mengundang tetangga terdekat sesuai kemampuan yang punya rumah. Karena dengan mengungkapkan rasa syukur melalui doa yang dipimpin oleh Bapak Haji atau ustad sudah merupakan syarat utama sebelum dan setelah rumah berdiri.

Orang-orang yang mengikuti syarat-syarat di dalam primbon adalah 
mereka yang belum terpengaruh oleh kehidupan kota. Masyarakat yang berada di pinggir kota atau jalan besar sudah mulai meninggalkan tradisi karena menurut mereka terlalu banyak materi yang harus disiapkan dan tidak mau repot. Di Desa Jiwan muncul perumahan-perumahan baru, pemborong ini hanya melakukan slametan saat peletakan batu pertama untuk syarat-syarat lain seperti sesaji tidak lagi diterapkan.

Membangun rumah juga bersamaan dengan membuat sumur. Sumur merupakan sumber rejeki, air merupakan bagian dari kehidupan. Air sumur akan dipakai selamanya bahkan secara turun temurun. Dengan demikian orang Jawa untuk membuat sumur ada perhitungannya sendiri. Cara menghitung pembuatan sumur dilakukan dengan proses ndepani (dengan bentangan tangan) yang dihitung dari rumah pokok. Didalam ramalan terdapat perhitungan sampai enam (5) dhepa, satu dhepa disebut Sri yang memiliki arti hasil pembuatan sumur bagus, air mengalir terus dan banyak rejeki. Dua dhepa dinamakan Donya artinya mudah kehilangan barang berharga di sumur. Tiga dhepa disebut Artha sumur sering kering. Empat dhepa dinamakan Swarga artinya air bagus dan bening, jika pemilik rumah mau bekerja keras, sumur itu akan menyebabkan banyak rejeki yang halal. Lima dhepa disebut Nraka yang artinya air mudah keruh dan berhawa panas (Suwardi Endraswara, 2010: 130-131).

\section{Simpulan dan Saran}

\section{Simpulan}

Dari uraian analisis diatas maka dapat disimpulkan tentang persepsi masyarakat Desa Jiwan terhadap kalender Jawa dalam membangun rumah bahwa mayoritas masyarakat Desa Jiwan masih memperhitungkan hal baik dengan melihat kalender Jawa yang dihubungkan dengan Primbon/ramalan nenek moyang sebab merupakan pengalaman orang tua yang tidak ada salahnya apabila dilaksanakan. Hal ini diturunkan kepada penerusnya agar tidak terjadi lagi halangan buruk yang akan menimpa keluarganya. Selain itu apabila mengabaikan dari ramalan tersebut banyak terbukti adanya halangan buruk yang terjadi, seperti misalnya membangun rumah saat terdapat keluarga yang sedang mengandung, bayi tersebut tidak akan selamat. Ada juga masyarakat yang mempercayai keberadaan primbon karena merupakan adat Jawa yang telah turun temurun dan suatu kepercayaan pribadi yang enggan bila ditinggalkan.

Kepercayaan masyarakat tentang keberadaan Primbon terutama menentukan hal-hal baik dalam melakukan acara penting seperti hajatan 
pernikahan, mendoakan keluarga yang meninggal dan dan khususnya dalam membangun rumah. Untuk membangun rumah mereka mencari hari baik dengan menghindari hari-hari naas. Kerangka atap rumah (molo) selalu terdapat balutan kain berwarna putih atau merah putih sebagai ciri khas bangsa Indonesia dan watak orang yang mempunyai rumah dapat berjiwa pemberani dan suci. Balutan kain tersebut diberi paku emas menandakan kewibawaan seseorang agar bersinar seperti emas. Selain itu mereka menyiapkan sesaji berupa ayam panggang dan perlengkapannya yang nantinya akan dibagikan kepada tetangga terdekat setelah dibacakan do'a oleh sesepuh. Tradisi ini merupakan simbol untuk menolak hal-hal buruk (tolak bala/ kejahatan/penyakit/halangan) akan tetapi mereka tidak melupakan ajaranajaran agama (percaya kepada Allah).

\section{Daftar Pustaka}

Abraham dan Yudi Hartono. 2008. Pengantar Antropologi (Bahan Ajar Untuk Perguruan Tinggi). Magetan: Lembaga Edukasi Swastika.

Abraham Dkk. 2009. Ilmu Sosial Dan Budaya Dasar. Magetan: LE-swastika Press.

Bamambang dan Melia. 2008. Social Mapping-Metode Pemetaan Sosial. Bandung: Rekayasa Sains.

Budiono Herusatoto. 1987. Simbolisme dalam Budaya Jawa. Yogyakarta: PT. Hanindita.

Ombak
Burhan Bungin. 2007. Penelitian Kualitatif. Jakarta: Kencana.

Dadang Supardan. 2008. Pengantar Ilmu Sosial. Jakarta: PT. Bumi Aksara.

Daldiono dan Wistodiyono. 2010. Ilmu Slamet (Merangkai Mutiara Filsafat Jawa di Era Modernisasi dan Globalisasi). Jakarta: PT. Bhuana Ilmu Populer.

Dede Oetomo (Eds). Metode Penelitian Sosial (Berbagai Pendekatan Alternatif). Jakarta: Kencana.

Djoko Suryo, dkk. 1985. Gaya Hidup Masyarakat di Pedesaan: Pola Kehidupan Sosial-Ekonomi dan Budaya. Proyek Penelitian dan Pengkajian Kebudayaan Nusantara.

Elly dkk. 2007. Ilmu Sosial Budaya Dasar. Jakarta: Kencana prenada Media Group.

Emy Susanti (Eds). 2008. Metode Penelitian Sosial (Berbagai Pendekatan Alternatif). Jakarta: Kencana.

Emzir. 2010. Metodologi Penelitian Kualitatif: Analisis Data. Jakarta: PT Raja Grafindo.

Fattah Hanurawan. 2010. Psikologi Sosial Suatu Pengantar. Bandung: PT. Remaja Rosdakarya Offset.

Harsojo. 1986. Pengantar Antropologi. Bandung: Binacipta.

Husaini dan Purnomo. 2004. Metodologi Penelitian Sosial. Jakarta: PT. Bumi Aksara.

Irawan Soehartono. 1999. Metode Penelitian Sosial. Bandung: PT Remaja Rosdakarya.

Jefta Leibo dan Nasikun, B. 1990. Sosiologi Pedesaan. Yogyakarta: Andi Offset.

Koenjaraningrat. 2009. Pengantar Ilmu Antropologi. Jakarta: PT. Rineka Cipta.

Mardalis. 2007. Metode Penelitian (Suatu Pendekatan Proposal). Jakarta: Bumi Aksara.

Miles, Matthew B. 1992. Analisis Data Kualitatif. Jakarta: UI- Press.

Muhammad Zaairul. 2011. Mutiara Hidup Manusia Jawa. Yogyakarta: Aditya Media Publishing.

Purwadi. 2009. Petungan Jawa. Yogyakarta: Pinus. 
Sarlito Wirawan. 2002. Psikologi Sosial (Individu dan Teori-teori Psikologi Sosial). Jakarta: Balai Pustaka.

Sugiyono. 2007. Metode Penelitian Kuantitatif, Kualitatif Dan $R \& D$. Bandung: Alfabeta.

2010. Metode Penelitian Pendidikan (Pendekatan Kuantitatif, Kualitatif dan R\&D). Bandung: Alfabeta.

Suharsimi. 1989. Prosedur Penelitian. Jakarta: Bina Aksara.

Suprihadi dan Soehartono. 1984. Desa Kita (Sosiologi Pedesaan). Banbung: Alumni.

Suwardi Endraswara. 2010. Falsafah Hidup Jawa. Yogyakarta: Cakrawala.

Thomas Wiyasa. 1988. Upacara Tradisional

Masyarakat Jawa. Jakarta: PT. Intermasa 